\title{
Article \\ Desert Locust Stopped by Tibetan Highlands during the 2020 Upsurge
}

\author{
Jun Liu ${ }^{1}$, Michel Lecoq ${ }^{2}$ and Long Zhang ${ }^{3, *}$ \\ 1 College of Grassland Science and Technology, China Agricultural University, Beijing 100193, China; \\ liujun2637096337@163.com \\ 2 French Agricultural Research Centre for International Development, Center for Biology and Management of \\ Populations, F-34398 Montpellier, France; mlecoq34@gmail.com \\ 3 Shandong Academy of Agricultural Sciences, Jinan 250100, China \\ * Correspondence: locust@cau.edu.cn
}

check for updates

Citation: Liu, J.; Lecoq, M.; Zhang, L. Desert Locust Stopped by Tibetan Highlands during the 2020 Upsurge. Agronomy 2021, 11, 2287. https:/ / doi.org/10.3390/agronomy11112287

Academic Editor: Andrea Sciarretta

Received: 27 September 2021

Accepted: 2 November 2021

Published: 11 November 2021

Publisher's Note: MDPI stays neutral with regard to jurisdictional claims in published maps and institutional affiliations.

Copyright: (c) 2021 by the authors. Licensee MDPI, Basel, Switzerland. This article is an open access article distributed under the terms and conditions of the Creative Commons Attribution (CC BY) license (https:// creativecommons.org/licenses/by/ $4.0 /)$.

\begin{abstract}
Desert locust is an important pest to agriculture. In 2019-2020, a major upsurge originated in the southern Arabian Peninsula and gradually spread to east Africa, then to south-west Asia, as far as Pakistan and India, even reaching Nepal, resulting in major agricultural losses. For the first time, a few swarms entered southern Tibet. Using field observations and experiments, we studied their path to the Tibetan plateau and their behavior at these very high altitudes. The locusts moved up the Tibetan valleys from low-lying areas $(1700 \mathrm{~m})$ to much higher elevations $(5400 \mathrm{~m})$. The low temperatures and high humidity put them under severe stress; their activities were limited, and they did not survive long or produce local offspring. It is clear that the high-altitude environmental conditions in the Himalayan mountains provided an important natural barrier that limited the northward expansion of the desert locust populations.
\end{abstract}

Keywords: Schistocerca gregaria; Tibet; high altitude plateau; invasion route; survival; natural barrier

\section{Introduction}

Desert locust, Schistocerca gregaria (Forskål, 1775) is an important pest to agriculture for many countries in Africa, the Middle East, and SW Asia. This polyphagous insect can cause damage to almost all types of vegetation and crops [1-3]. It is endowed with a high reproductive potential under favorable rainfall conditions [1,4,5], as well as a great capacity for flight, frequently migrating hundreds of kilometers, sometimes even over oceans [6,7]. The transition from a solitary to a gregarious phase is another characteristic of the desert locust that depends on population density, and locusts in the gregarious phase can migrate long distances in large swarms and cause huge crop losses [8-11].

In general, the desert locust is mainly distributed in arid and semi-arid regions from the Sahara through the Arabian Peninsula to southwest Asia in lowland areas [3,4,12-14]. This recession area covers around $19 \mathrm{M} \mathrm{km}^{2}$. During invasions, desert locusts can spread over larger territories (an invasion area of $31 \mathrm{M} \mathrm{km}^{2}$ ) and reach the limits of the areas they can colonize, often unfavorable for breeding, but where they can still cause significant damage. This is the case of the humid woodlands of Africa to the south, or the too cold and mountainous regions to the north. Until now, in the Asian part of its range, the northern mountains (such as Himalayas and Kunlun Mountains with and average altitude of $4000 \mathrm{~m}$ ) seemed to constitute an uncrossable barrier. Particularly in the southern end of the range, if northern India and Nepal have sometimes been colonized, no swarms have ever been reported from Tibet. Yet, this is what has happened recently.

In 2019 and 2020, the desert locust again threatened large areas of east Africa, the near east, and south-west. The upsurge originated in the desert regions of Arabia that received exceptional rainfall. The Food and Agriculture Organization of the United Nations (FAO) described this as the most severe locust situation in decades [15-17]. To the south, swarms 
invaded much of eastern Africa, reaching Kenya, Uganda, and Tanzania, which have not faced a threat of this magnitude in 70 years. To the east, from March 2019, the invasion spread to Iran, Pakistan, and India, even reaching Nepal, and for the first time Tibet [15-18]. In particular, in June 2020, locust swarms invaded Nepal, and some of them reached the foot of the Himalayas [17]. Until now, there had been no reports of locust swarms in the Tibetan highlands. It was considered that swarms cannot cross high mountain ranges such as the Atlas Mountains, the Hindu Kush, or the Himalayas and that the temperature was too cold for the desert locust at these high altitudes. During past major desert locust invasions, and even though northern India was widely contaminated, no desert locusts had been reported in Tibet. While Nepal is included by Waloff in the range of the desert locust, Tibet is not [19-21]. Only a solitary phase adult female has been reported in Tibet, collected by Zhang Xue Zhong, on 29 April 1974, in the Zhangmu area of Nyalam County (about $28^{\circ} 20^{\prime} \mathrm{N}, 86^{\circ} \mathrm{E}$, altitude $2250 \mathrm{~m}$ ) [22,23]. According to Cai [24], the desert locust is also present in Yunnan (China), but there is no specific information to support this assertion. We believe that this is mainly an assumption based on Yunnan's proximity to neighboring areas of Burma known to be part of the desert locust invasion area. However, in early July 2020, during this new upsurge, as swarms advanced from Iran, Pakistan, India, and Nepal, seven counties or cities in Tibet reported light swarms of locusts, clearly originating in Nepal. Some were recorded at very high altitudes, around $4000 \mathrm{~m}$ or more.

Although the risk of desert locusts invading the high-altitude Tibetan plateaus and causing damage was low, the Tibet Forestry and Grass Bureau, Lhasa Customs, and other departments have initiated prevention and control monitoring work and issued specific prevention and control and emergency plans [25]. However, even with a near-zero risk, this situation offered the first opportunity to study locusts in these cold, high-altitude areas. How could these swarms invade Tibet and enter the Himalayan range in 2020? What was their fate in these high-altitude areas? Using field observations and experiments, we studied for the first time the path of the desert locust to the Tibetan plateau, as well as its behavior, feeding, maturation, and survival in this region, providing valuable information for eventual forecasting.

\section{Material and Methods}

Between early July and late September 2020, field surveys were conducted in seven localities in southern Tibet where desert locusts were reported: Pulan, Zhongba, Saga, Nyalam, Chentang, Jilong, and Dingri counties (Figure 1). These sites benefit from a wide range of climates: semi-arid in the intense cold zone of the Tibetan plateau (mean annual temperature, $\mathrm{T}=6{ }^{\circ} \mathrm{C}$, and annual rainfall, $\mathrm{R}=280 \mathrm{~mm}$ : Saga) or sub-cold $\left(\mathrm{T}<20^{\circ} \mathrm{C}\right.$ and $\mathrm{R}=173 \mathrm{~mm}$ to $280 \mathrm{~mm}$ : Pulan and Zhongba, respectively); temperate semi-humid climate, with low temperature and $\mathrm{R}=618 \mathrm{~mm}$ (Nyalam); monsoon climate, whether subtropical (mild climate and heavy rainfall in summer and autumn: Chentang), mountain subtropical ( $\mathrm{T}=10-13{ }^{\circ} \mathrm{C}, \mathrm{R}=1000 \mathrm{~mm}$ : Jilong), or semi-arid temperate $\left(\mathrm{T}=12{ }^{\circ} \mathrm{C}\right.$, $\mathrm{R}=319 \mathrm{~mm}$ : Dingri).

We focused, in particular, on Nyalam County (ranging from 1700 to $4800 \mathrm{~m}$ ) and the Boqu River valley, flowing from the north to the south and opening towards Nepal at the level of Zhangmu town (Figure 1). This valley is one of the areas where locust swarms appear to have entered Tibet, obviously from Nepal where locusts have been reported in abundance and where the greatest number of swarm reports have been made. This valley was monitored daily in July and August 2020, except on rainy or foggy days.

Study sites included rugged and steep mountainous areas, riverbanks, sandy lands, and a wide variety of plant communities (Figure 2). Field monitoring focused on locust density per square meter, sex ratio, maturity, and ovary development status within desert locust populations. At least five locust samples were collected from each sampling site. The sex ratio was estimated on a larger number of individuals collected by hand in the morning when the locusts were still inactive. The maturity status of the population was determined based on the appearance of ovaries and ovarioles (immature: white 
ovarioles, small and not clearly visible; mature 1: white ovarioles, larger, oocytes starting to develop; mature 2: yellow ovarioles, larger with clearly developing oocytes; mature 3: ovarioles containing well-formed eggs, almost ready for laying; laying: distended, enlarged abdominal segments, no eggs in abdomen).

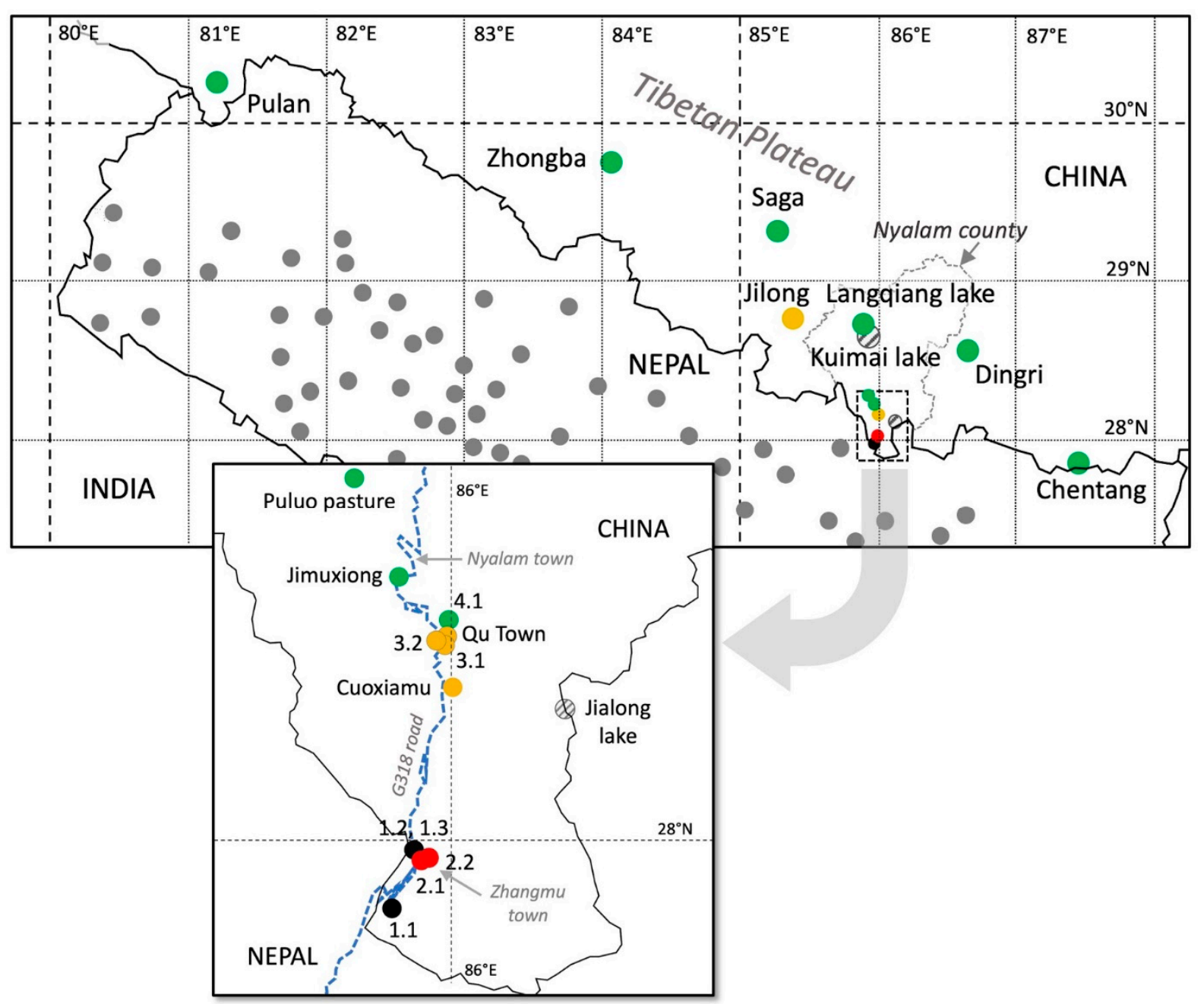

Figure 1. Desert locust records in Tibet in July 2020. Colored dots indicate the abundance of desert locust populations in Tibet: gray striped, none; green,very light/light; yellow, middle; red, heavy; black, very heavy. The gray dots in Nepal indicate desert locust reports (swarms or scattered populations) between June 27 and July 16 (modified from Shrestha et al., 2021). The box below the general map details the situation in southern Nyalam County where the degree of infestation was the most serious, along the G318 road (blue dotted line), for about $26 \mathrm{~km}$ along the Boqu River valley (1700 to $4200 \mathrm{~m}$ ).

Caging experiments were conducted in the field to observe and record daily life habits, mating, breeding, and longevity of desert locusts. They were conducted in two sites: Zhangmu (2300 m) and Nyalam (3800 m) (Figure 1). Gregarious locust adults were collected in the field for rearing in cages with Lolium perenne (Gramineae) leaves. The cages measured $70 \times 70 \times 70 \mathrm{~cm}$, had a wooden frame, and were covered with wire mesh. In Zhangmu, 6 cages contained 10 adults each ( 5 males and 5 females) while in Nyalam, 2 cages were used, each containing 27 locusts (18 females and 9 males).

In addition, food preference tests were implemented. Healthy and active adult locusts were collected from Zhangmu in July 2020 and reared in cages under natural conditions. The tested locusts were starved for $12 \mathrm{~h}$ and then placed individually in a transparent plastic cylindrical bottle (60 $\mathrm{mm}$ diameter, $200 \mathrm{~mm}$ length). Leaves, freshly collected on the morning of the test, were inserted into the bottles, with all leaves of the same plant being the same size as far as possible. Thirty-four plant species, collected in the region, were 
tested. At least 10 adults ( 5 males and 5 females) were fed each plant species. Leaves were removed after $24 \mathrm{~h}$ and the area consumed was measured to assess feeding preferences according to the following scale: high $>1700 \mathrm{~mm}^{2}$, medium $>650 \mathrm{~mm}^{2}$, low $>100 \mathrm{~mm}^{2}$; very low $<100 \mathrm{~mm}^{2}$.
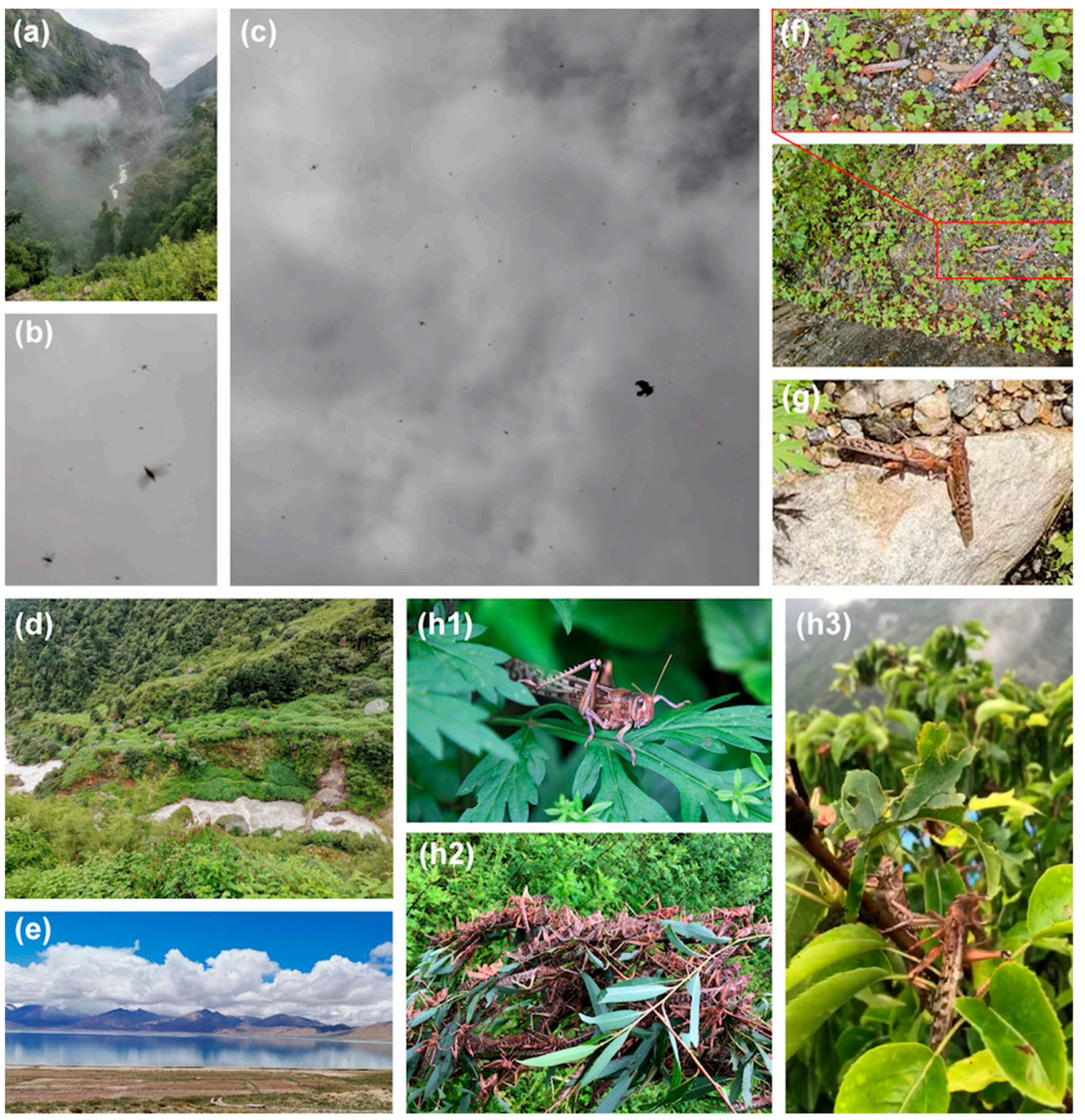

Figure 2. Some views of desert locusts in southern Tibet, in 2020, not far from the border with Nepal. (a) A valley having been invaded. (b,c) Light swarms of locusts flying in the clouds at about $3000 \mathrm{~m}$. (d) The Boqu River valley at $3360 \mathrm{~m}$. (e) Landscape at $4670 \mathrm{~m}$ altitude with lakes, sandy beaches, and a rare vegetation. (f) Desert locusts found dead in the field at an altitude of $3350 \mathrm{~m}$. (g) basking in the sun on stones, or (h1-h3) feeding on wormwood and willow leaves.

We used Graphpad Prism 8.0 for statistical analyses. For food preference tests, Graphpad Prism 8.0 was used to draw the leaf area consumed, imageJ 1.8.0 to measure this area, and unpaired $t$-test or one-way ANOVA for comparisons.

\section{Results}

\subsection{Desert Locust Penetration in the Tibetan Highlands}

From July 1 to 9, 2020 at least 7 counties in Tibet (Chentang, Dingri, Nyalam, Jilong, Pulan, Saga, Zhongba) reported adult locusts near the border with Nepal. These counties are characterized by valleys opening at a lower altitude at the border with Nepal. The 
largest swarm appeared in Zhangmu District (Nyalam County), and another in Jilong County at an altitude of about $1700 \mathrm{~m}$. However, small groups of locusts have also appeared at altitudes above $4000 \mathrm{~m}$ (Figure 1, Table 1). How did they manage to climb to such places in the Himalayas? To answer this question, we mainly surveyed Nyalam County, from the lower elevations around $1700 \mathrm{~m}$, up to $4200 \mathrm{~m}$, following the G318 road for about $26 \mathrm{~km}$ along the Boqu River valley, passing through Zhangmu and Nyalam towns. This valley opens to the south at the China-Nepal border (Figure 2a) and gradually rises northward from 1700 to $3800 \mathrm{~m}$.

Table 1. Monitoring sites and assessment of desert locust numbers along some valleys in South Tibet.

\begin{tabular}{ccccc}
\hline Sites & Altitude $(\mathbf{m})$ & Locust Density & Latitude & Longitude \\
\hline Saga (Jilong valley) & 5400 & Light & $29^{\circ} 19^{\prime} 48^{\prime \prime}$ & $85^{\circ} 13^{\prime} 56^{\prime \prime}$ \\
Zhongba (Zhongba County) & 4800 & Light & $29^{\circ} 46^{\prime} 12^{\prime \prime}$ & $84^{\circ} 01^{\prime} 53^{\prime \prime}$ \\
Jialong Lake & 4750 & None & $28^{\circ} 03^{\prime} 54^{\prime \prime}$ & $86^{\circ} 03^{\prime} 43^{\prime \prime}$ \\
Kuimai lake & 4725 & None & $28^{\circ} 40^{\prime} 52^{\prime \prime}$ & $85^{\circ} 56^{\prime} 27^{\prime \prime}$ \\
Langqiang Lake & 4670 & Very light & $28^{\circ} 43^{\prime} 26^{\prime \prime}$ & $85^{\circ} 53^{\prime} 31^{\prime \prime}$ \\
Puluo pasture & 4200 & Very light & $28^{\circ} 10^{\prime} 39^{\prime \prime}$ & $85^{\circ} 56^{\prime} 47^{\prime \prime}$ \\
Jimuxiong & 3750 & Very light & $28^{\circ} 08^{\prime} 33^{\prime \prime}$ & $85^{\circ} 58^{\prime} 17^{\prime \prime}$ \\
Pulan (Pulan valley) & 3600 & Light & $30^{\circ} 16^{\prime} 05^{\prime \prime}$ & $81^{\circ} 10^{\prime} 06^{\prime \prime}$ \\
Jilong (Jilong valley) & 3530 & Middle & $28^{\circ} 45^{\prime} 01^{\prime \prime}$ & $85^{\circ} 21^{\prime} 47^{\prime \prime}$ \\
4.1 & 3380 & Light & $28^{\circ} 06^{\prime} 27^{\prime \prime}$ & $85^{\circ} 59^{\prime} 55^{\prime \prime}$ \\
Qu Town & 3365 & Middle & $28^{\circ} 05^{\prime} 49^{\prime \prime}$ & $85^{\circ} 59^{\prime} 46^{\prime \prime}$ \\
3.2 & 3350 & Middle & $28^{\circ} 05^{\prime} 59^{\prime \prime}$ & $85^{\circ} 59^{\prime} 50^{\prime \prime}$ \\
3.1 & 3340 & Middle & $28^{\circ} 05^{\prime} 45^{\prime \prime}$ & $85^{\circ} 59^{\prime} 46^{\prime \prime}$ \\
Chentang (Chentang valley) & 3300 & Light & $27^{\circ} 51^{\prime} 39^{\prime \prime}$ & $87^{\circ} 25^{\prime} 13^{\prime \prime}$ \\
Dingri (Gama valley) & 3200 & Light & $28^{\circ} 34^{\prime} 00^{\prime \prime}$ & $86^{\circ} 38^{\prime} 00^{\prime \prime}$ \\
Cuoxiamu & 3150 & Middle & $28^{\circ} 04^{\prime} 37^{\prime \prime}$ & $85^{\circ} 59^{\prime} 54^{\prime \prime}$ \\
2.2 & 2500 & Heavy & $27^{\circ} 59^{\prime} 37^{\prime \prime}$ & $85^{\circ} 59^{\prime} 8^{\prime \prime}$ \\
2.1 & 2350 & Heavy & $27^{\circ} 59^{\prime} 34^{\prime \prime}$ & $85^{\circ} 58^{\prime} 57^{\prime \prime}$ \\
1.3 & 2330 & Very heavy & $27^{\circ} 59^{\prime} 50^{\prime \prime}$ & $85^{\circ} 58^{\prime} 47^{\prime \prime}$ \\
1.2 & 2320 & Very heavy & $27^{\circ} 59^{\prime} 50^{\prime \prime}$ & $85^{\circ} 58^{\prime} 47^{\prime \prime}$ \\
1.1 & $\mathbf{1 9 5 0}$ & Very heavy & $27^{\circ} 58^{\prime} 09^{\prime \prime}$ & $85^{\circ} 57^{\prime} 54^{\prime \prime}$ \\
\hline
\end{tabular}

Estimated degree of desert locust density (number of locusts seen per site): Very heavy $>10,000$ (black), heavy $>100$ (red), middle 50-100 (brown), light 10-50 (green), very light <10 (light green). Unless otherwise indicated, all sites belong to the Boqu River valley in the Nyalam County.

The largest swarms were observed in Bang and Lixin villages $(1700 \mathrm{~m})$ in Zhangmu District, downstream of the Boqu River valley near its opening to Nepal (Figure 1 and Table 1, sites 1.1,1.2,1.3). The population size was estimated to be over 0.4 million adults. Locusts rested on both trees (mainly bamboo, but also willow, pine, and fir) and herbaceous vegetation at the base of valley cliffs (Figure 2a,h1-h3). On sunny or slightly cloudy days, locusts formed a large, cumuliform swarm. Crows and other birds were observed catching locusts in flight (Figure 2c). Some locusts formed into stratiform swarms migrating upward along the valley midway up the slope tops (Figure $2 b$ ). The size of each migrating group varied from several hundred to several thousand adults. During flight, many individuals fell into the river or landed on the road or mountain slopes.

Along the valley, at three sites between 2500 and $3200 \mathrm{~m}$ (Table 1, sites Cuoxiamu, $2.1,2.2)$ locusts were observed forced to stop their flight by strong winds. Hundreds of individuals were found gathered on trees or in the grass. At four other sites located in the same valley at an altitude above $3300 \mathrm{~m}$ (Table 1, sites Qu town, 3.1, 3.2, 4.1), at a place where the river makes many bends, locusts were observed grouped on the ground (Figure 1). In Qu town (at $3365 \mathrm{~m}$ ), a few locusts were found on the banks of the river as well as at the foot of the high cliffs, covered with lush vegetation, that overlook it (Figure $2 \mathrm{~d}, \mathrm{f}$ ). Some were dead, others alive and basking on the rocks on sunny days (Figure $2 \mathrm{~g}$ ). The same situations were observed at the three other sites (Sections 3.1, 3.2 and 4.1). 
The Boqu River valley ends near Nyalam, at about 3800 m elevation (Figure 1 and Table 1, Jimuxiong site). Several scattered locusts were observed flying in this area, with flight speed estimated at about $6 \mathrm{~m} / \mathrm{s}$. A few adults were also collected locally in potato fields. At Puluo pasture ( $4200 \mathrm{~m})$, about $25 \mathrm{~km}$ northwest of Nyalam, 6 locusts were found in early July (Figure 1 and Table 1). On the shores of Langqiang (4700 m) and Kuimai $(4725 \mathrm{~m}$ ) lakes, about $30-40 \mathrm{~km}$ north of Nyalam, a few locusts in flight were observed as well as a few dead locusts in late July (Figure 2e, Table 1). It is interesting to note that while locusts were observed at Cuoxiamu, none were seen at Jialong Lake, although both sites are located at almost the same latitude (about $28^{\circ} 4^{\prime}$ ), but the former in the Boqu River valley at $3150 \mathrm{~m}$, while the latter, at $4750 \mathrm{~m}$, is outside this valley about $10 \mathrm{~km}$ to the east.

\subsection{Population Dynamics of the Desert Locust in Tibet in 2020}

\subsubsection{Field Survey}

Field surveys were conducted in areas at elevations from of $2300 \mathrm{~m}$ to $4750 \mathrm{~m}$, from mid-July to early October 2020.

In Zhangmu, at $2300 \mathrm{~m}$, from 13 to $27 \mathrm{July}$, the average density of locusts at surveyed sites gradually decreased from 3.1 locusts $/ \mathrm{m}^{2}$ to zero from $27 \mathrm{July}$. After this date, desert locusts were no longer observed in this area (Figure 3a). Twenty-five live females were collected on 25 July, and 38 and 177 dead females on 1 and 11 August. Females were dominant and the sex ratios on these dates were $60 \%, 68.4 \%$, and $71.2 \%$, respectively (Figure 3b, column graph). On August 1, all females were immature and on August 11, only $1.3 \%$ of the females were at maturity stage 1 (Figure $3 \mathrm{~b}$, pie chart).

(a)

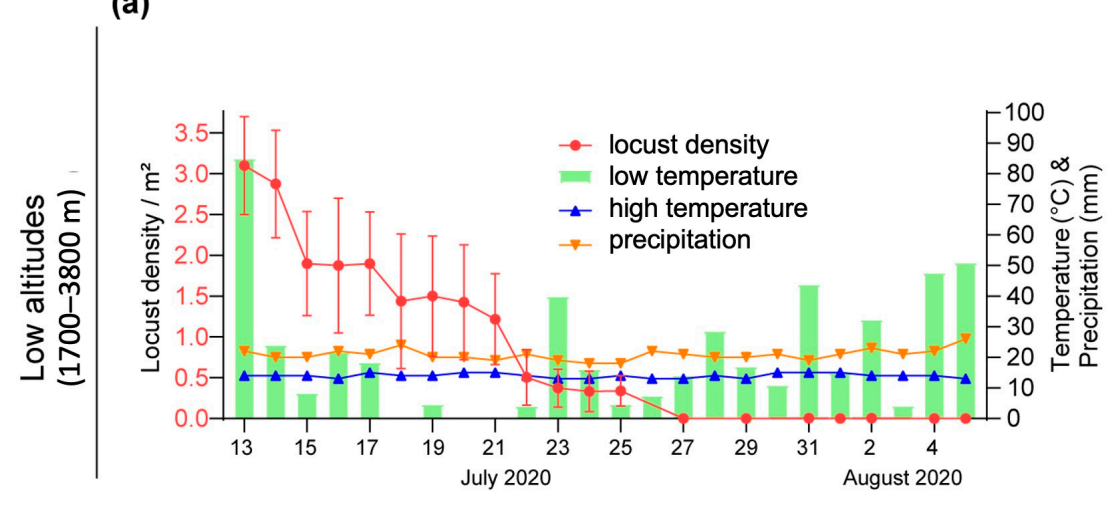

(b)

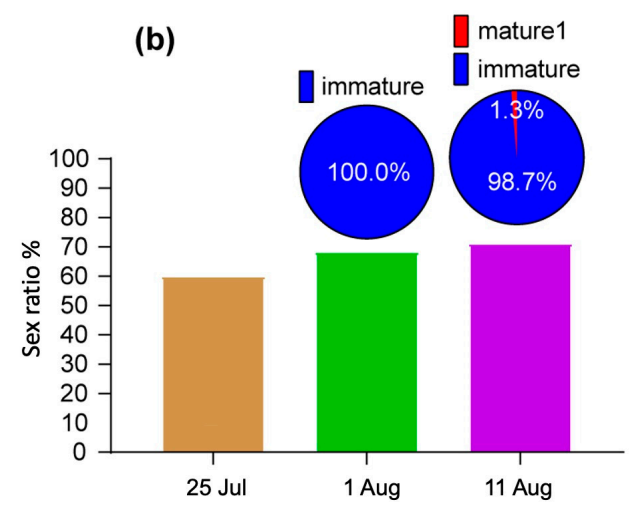

(c)

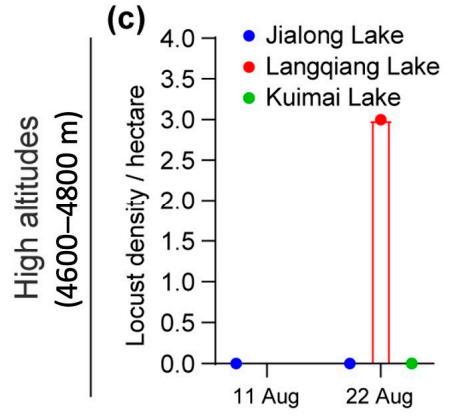

(d)

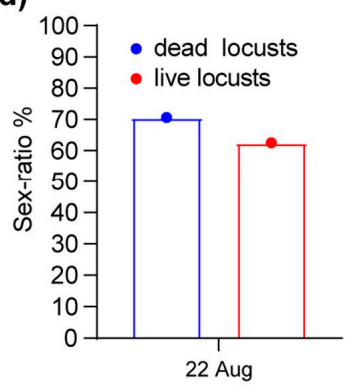

(e)

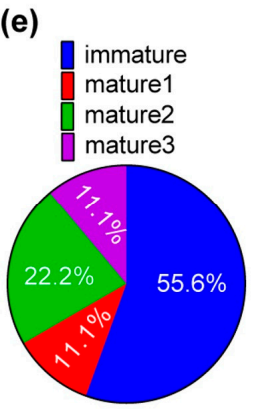

(f)

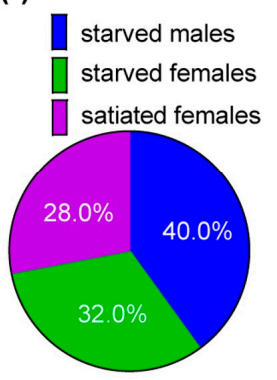

Figure 3. Desert locust field monitoring in low and high altitudes in Nyalam County, Tibet, in July-August 2020. Lower altitudes: changes in locust average density as a function of temperature and rainfall (a), locust sex ratio and ovarian development (b). Higher altitudes: locust density at three sites (c), sex ratio (d), ovarian development (e). Filling degree of the digestive tract of locusts collected in the field (f).

Weather conditions must have been unfavorable for the desert locusts. In Zhangmu, the temperature was relatively low and stable during the survey period, with the average ranging from $14.0^{\circ} \mathrm{C}$ to $20.8{ }^{\circ} \mathrm{C}$, and the lowest temperature being about $10{ }^{\circ} \mathrm{C}$. In Qu City, in the middle of the Boqu River valley, the temperature was even lower, with an 
average of 5 to $8{ }^{\circ} \mathrm{C}$ due to heavy rainfall, higher elevation, and strong wind. It rained almost every day and only three days had no rain. The highest rainfall was recorded on July 13 with $85.2 \mathrm{~mm}$. On July 14,16, and 17, more than $18 \mathrm{~mm}$ of rain fell, and on July 23 more than $40 \mathrm{~mm}$. Since desert locusts prefer higher temperatures and drier weather, the low temperatures and sustained rainfall are expected to have been a major stress on these insects, resulting in high mortality and population loss in this area in late July.

At higher elevations, Jialong (4750 m), Langqiang (4670 m), and Kuimai (4725 m) lakes were monitored (Figure 1). No locusts were found near Jialong (11 and 22 August) and Kuimai lakes (22 August). Only at Langqiang lake were locusts observed on 22 August, at a low density of only 3 locusts/ha (Figure 3c). On the lake shore, some locusts were feeding or resting on shrubby plants such as acacia trees. A few dead locusts were also observed. On a sunny day, when the maximum temperature of the day was above $20{ }^{\circ} \mathrm{C}$, a few locusts were observed flying $2-3 \mathrm{~m}$ above the ground in various directions at a speed of about $10 \mathrm{~m} / \mathrm{s}$. The distance flown in a single flight was about $20-50 \mathrm{~m}$. The sex ratio was $70.6 \%$ and $62.5 \%$ for dead $(n=38)$ and live $(n=16)$ locusts, respectively (Figure $3 \mathrm{~d})$. Live females were mostly immature $(55.6 \%)$, with the remainder in various stages of maturity (Figure 3e). No females had yet laid eggs. It appears that locusts lived longer in these drier, higher areas (above $3700 \mathrm{~m}$ ) than in the lower $(2300 \mathrm{~m})$, very rainy areas.

Examination of the digestive system of locusts $(n=25)$ collected from Qu town area revealed that $72.0 \%$ of individuals were starved, including $53.3 \%$ of females and $100.0 \%$ of males (Figure 3f). Locust feces were liquid, probably due to the high humidity throughout the valley.

As of late July 2020, no swarms were observed in all previously infested areas and only dead locusts were found throughout the Boqu River valley.

\subsubsection{Field Caging Experiments}

At the same time, in Zhangmu and Nyalam, cage field studies were conducted. In Zhangmu (20 July to 4 August) locust life span averaged 26 days, ranging from 22 to 35 days. Probably under the influence of heavy rains, survival rate dropped sharply from $95 \%$ to $38 \%$ between July 22 and 25, and from 37\% to $10 \%$ from July 26 to 28 . On 4 August, no locusts were alive (Figure 4a). These figures are consistent with field observations made at the same time in this area (Figure 3a). This is despite the fact that locusts in cages were provided with sufficient food each day. In addition, $90 \%$ of the females were immature in the caged field studies, and no mating behavior was observed (Figure $4 \mathrm{~b}$ ), which is also very similar to the field study. These results confirm that low temperatures and high precipitation are critical limiting factors for locust survival in the southwestern Himalayan foothills.

In Nyalam (where the experiments were conducted from July 26 to October 18), the average lifespan of locusts was 70.9 days, with the longest being 110 days. The survival rate in the cages gradually decreased from $100 \%$ to $52 \%$ in 56 days from 26 July to 19 September. After the heavy rains on 23 and 24 September, survival continued to decline and then dropped rapidly after 10 October until the locusts disappeared completely on 18 October (Figure 4c). During the first 59 days, low precipitation occurred on 38 days (64.4\%), and the mean daily temperature ranged from $8.7^{\circ} \mathrm{C}$ to $18.8^{\circ} \mathrm{C}$. On September 23 and 24, heavier precipitation occurred $(22.3$ and $31.3 \mathrm{~mm})$ followed by a sharp drop in temperature (daily average ranging from $10.5^{\circ} \mathrm{C}$ and $1.5^{\circ} \mathrm{C}$ between September 19 and October 18). Precipitation ceased after September 25 (Figure 4c).

Thus, locust mortality in the field cages in both areas was also clearly influenced by temperature and rainfall. Heavy precipitation seems a key factor, but low average temperatures over a long period and low minimum temperatures can also be critical.

All arriving locusts were pinkish and immature. Under the low temperatures prevailing from July to October, ovarian development of females was very slow. Twenty-six females could be dissected to examine the ovaries. On August 1, the females were immature. Early maturation stage 1 was observed on August 12, stage 2 on August 15, stage 3 on 
September 10, and the only female (over 26) that laid eggs was observed on October 5 . The egg-pod contained 78 eggs (Figure 4f), but none hatched after incubation in the laboratory (L:D $=12: 12, \mathrm{~T}=35^{\circ} \mathrm{C}, \mathrm{RH}=30 \%$ ).

(a)

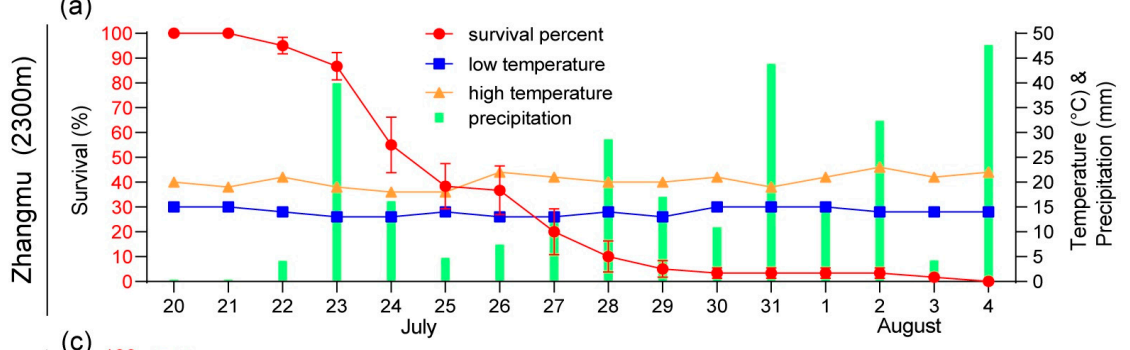

(c)

(c) (b)

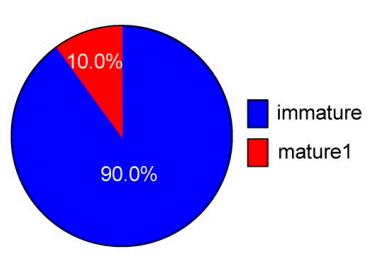

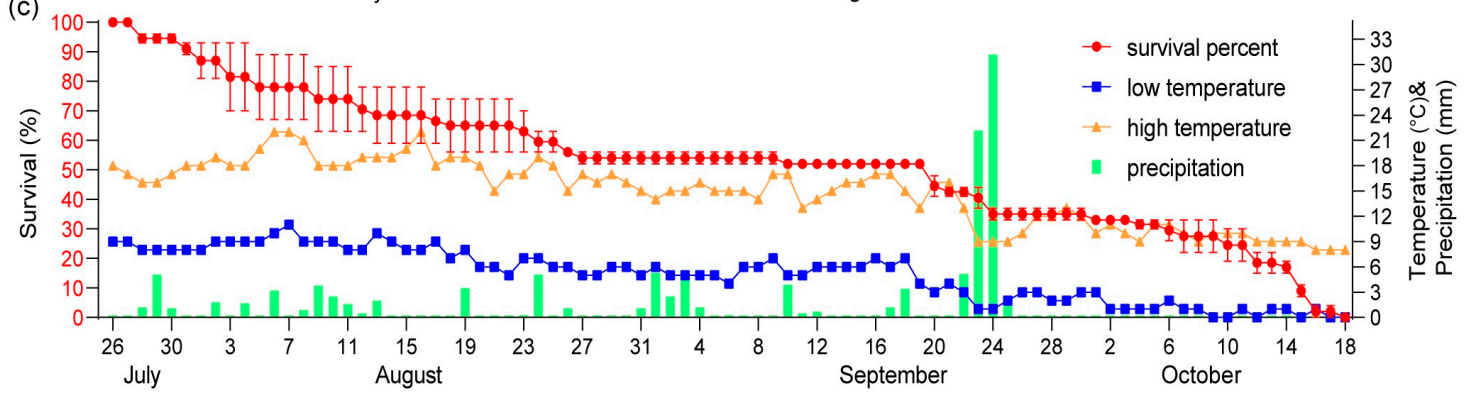

(d)

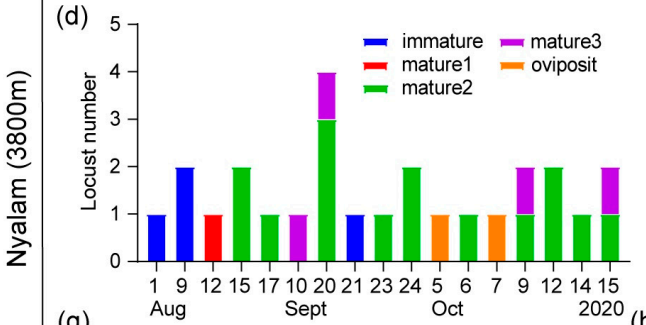

(e)

(f)
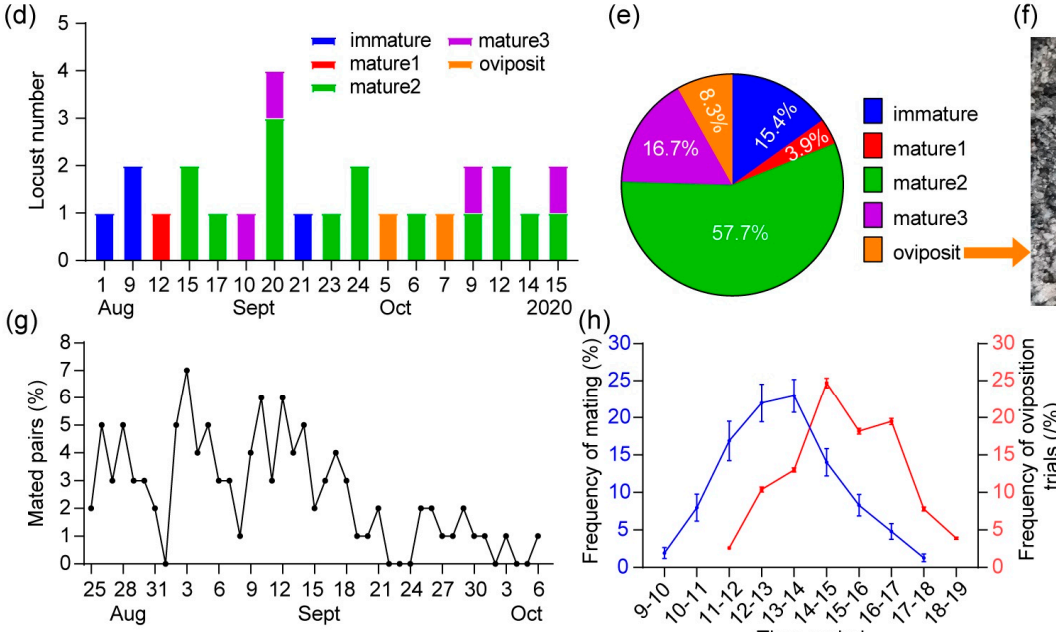

(i)

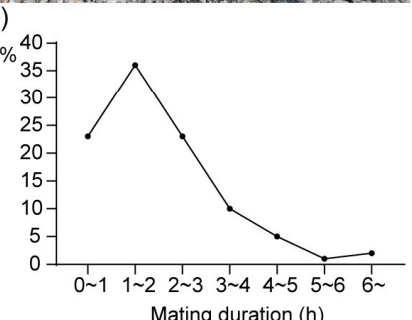

Figure 4. Cage field studies in Zhangmu $(2300 \mathrm{~m})$ and Nyalam $(3800 \mathrm{~m})$. Desert locust survival and weather conditions in Zhangmu (a) and Nyalam (c) in 2020 (the \% of survival is the mean of survival percentages per cage). Percentage of maturation of females in Zhangmu (b). In Nyalam: Number (d) and percentage (e) of maturation status of females; eggs in the ootheca (f); daily mating rate of locusts (g); mating (left) and pre-oviposition behavior (right) rates (h); mating duration (\%) (i).

In the cage study, adults mated many times during their lifetime, especially on sunny days and when the temperature was above $10^{\circ} \mathrm{C}$. However, no mating occurred on cloudy and rainy days. The period during which mating pairs were observed was very long, ranging from late August to early October, or 43 days. The vast majority (91\%) of matings occurred from 25 August to 18 September, or 25 days (Figure 4g). During the day, matings could be observed from 09:00 to 18:00, but most (75.7\%) occurred between 11:00 and 15:00 (Figure 4h). The duration of mating varied from a few minutes to several hours; $36 \%$ lasted $1-2 \mathrm{~h}$; the longest being $19 \mathrm{~h}$, probably due to the low evening temperatures that made the locusts not very active (Figure 4i). At the time of oviposition, the female makes regular movements of opening and closing the ovipositor valves and the abdomen elongates significantly. The whole oviposition process usually lasted a few minutes but 
could sometimes last several tens of minutes. Overall, oviposition lasted about $2 \mathrm{~h}$ and eggs were deposited in sandy soil at a depth of about $12 \mathrm{~cm}$. Pre-oviposition behavior (females using their abdomen to test whether the soil is suitable for oviposition) were observed from 11:00 to 18:00, but 75.3\% occurred from 14:00 to 17:00 (Figure 4h). When the temperature reached $15^{\circ} \mathrm{C}$ at noon in August and September, locusts flew into the cages but could still be hit easily.

\subsubsection{Food Preference Tests}

Most of the desert locusts (72\%) collected on the Tibetan Plateau were starving, with an empty digestive tract (Figure $3 \mathrm{f}$ ). In addition to the fact that low temperatures must have reduced feeding activity, we questioned whether or not local plants might be favorable and conducted food preference tests. A total of 34 local plant species (belonging to 19 families and 32 genera) were collected from Zhangmu area and presented to adult desert locusts (Figure 5). Only three plants were clearly consumed: Lophatherum gracile (LG), Mentha canadensis (MC), and Fagopyrum esculentum (FE) with, respectively, 2600, 1850, and $1400 \mathrm{~mm}^{2}$ of leaf area consumed in $24 \mathrm{~h}$. For the other plants, the consumed surface was lower or largely lower than $1200 \mathrm{~mm}^{2}$ and ten plants were not or very little consumed.

(a)

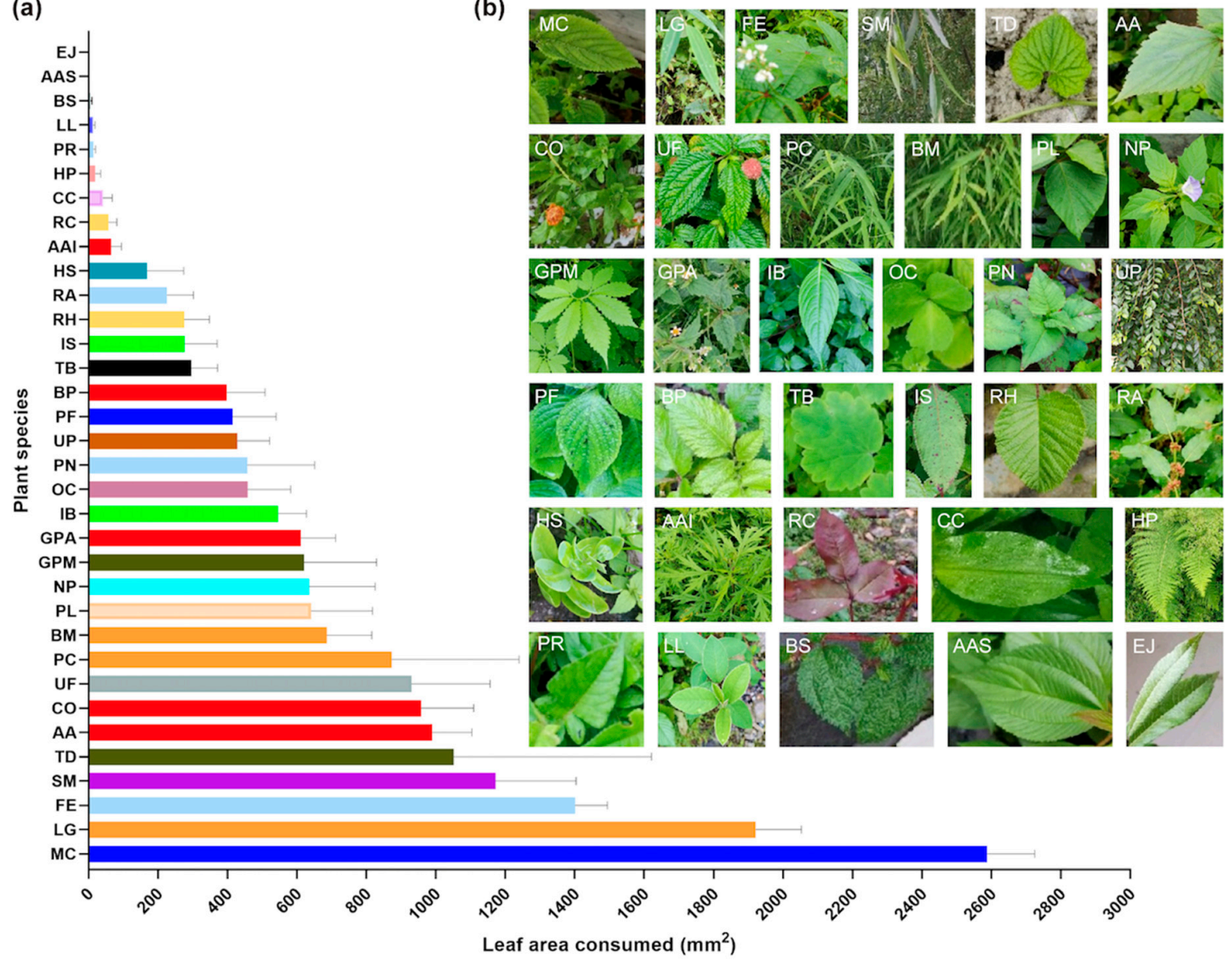

Figure 5. Desert locusts' food preferences for some Tibetan plants. (a) Leaf area consumed by locusts $(n=10$, female:male = 1:1; same color bars represent plants of the same family). (b) Leaf aspect of the 34 plant species tested: MC, Mentha canadensis (syn. M. haplocalyx); LG, Lophatherum gracile; FE, Fagopyrum esculentum; SM, Salix matsudana; TD, Thladiantha dubia; AA, Ageratina adenophora (syn. Eupatorium adenophorum); CO, Calendula officinalis; UF, Urtica fissa; PC, Pogonatherum crinitum; BM, Bambusa multiplex; PL, Pueraria lobata; NP, Nicandra physalodes; GPM, Gynostemma pentaphyllum; GPA, Galinsoga parviflora; IB, Impatiens balsamina; OC, Oxalis corniculata; PN, Polygonum nepalense; UP Ulmus pumila; PF, Perilla frutescens; BP, Bidens pilosa; TB, Thalictrum baicalense; IS, Impatiens siculifer; RH, Rubus hirsutus; RA, Rumex acetosa; HS, Hylotelephium spectabile (syn. Sedum spectabile); AAI, Artemisia argyi; RC, Rosa chinensis; CC, Commelina communis; HP, Hypolepis punctata; PR, Polygonum runcinatum; LL, Ligustrum lucidum; BS, Boehmeria spicata; AAS, Acalypha australis; EJ, Eriobotrya japonica. 


\section{Discussion}

\subsection{Desert Locust Routes in Tibet in July 2020}

The Himalayas, with their high altitudes and low temperatures, may seem an insurmountable natural barrier for locusts despite the great flight ability of these insects. However, some swarms have managed to penetrate it and our observations show that some isolated locusts have even been able to advance to very high areas. In fact, the valleys - thanks to the associated aerological systems - were the gateways of the locusts to the Tibetan highlands.

The highest concentrations of locusts in Tibet in 2020 were recorded along the Boqu River valley, with the highest densities observed south of the valley near the Nepalese border and at low elevations of only $1700 \mathrm{~m}$ (Figure 2a). Based on the observations, the flight path of the swarms mainly followed the river valley and gradually rose toward the Tibetan high plateau to an altitude of about $3200 \mathrm{~m}$. Outside the valley floor, the density was much lower. Density decreased as one moved northward and elevation increased. A few isolated locusts were able to progress, still following the valley, to much higher areas between 3200 and $5400 \mathrm{~m}$. They did not migrate in large swarms, but in small groups with several stops in the climbing route. These locusts do not seem to have been able to benefit from thermal lift that would have allowed them to rise to high altitudes, sometimes to the top of the convective layer at heights of 1 to $2 \mathrm{~km}$ [26]. The aerological conditions forced them to fly at low altitude, at a few tens of meters from the ground, while going up very gradually the bottom of the valley, until reaching too high altitudes where the thermal conditions must have ended up preventing them from flying. The observed flight speed along the Boqu River was only about $6 \mathrm{~m} / \mathrm{s}$, which is not much different from the average speeds of 7-18 m/s reported in the locust's usual habitat range [27,28]; however, the flights were only of short duration. The progression of these locusts up the valley must have been aided by slope and valley breezes, blowing from the bottom up during the day, at the time of locust flight activity. It is known that transport by such anabatic winds can account for the frequent occurrence of grasshoppers in mountainous areas at altitudes well above their area of residence [29], as well as for the movement of desert locust swarms to and on mountain slopes [30] (see Appendix A).

This Boqu River valley is surely only one of the entry routes of the desert locust into Tibet in July 2020. At the same time, desert locusts are widely reported throughout Nepal, immediately to the south. This country was invaded in three successive waves, on 25-29 June, 12 July, and 16 July. The swarms then spread over much of Nepal in about 10 days [31,32] (Figure 1). This Himalayan region on the southern border of Tibet has four valleys (ChenTang, Gama, Zhangmu, and Jilong) leading into Nepal and of relatively low altitude. All these valleys could thus have been, like the Boqu River valley studied here, an access route to invade southern Tibet from the beginning of July.

\subsection{High Altitude Climate as a Major Obstacle for Desert Locusts}

Once in Tibet, the high-altitude climate must have been a major obstacle to entry, reproduction, and local survival for locust individuals. The desert locust's usual range, its recession area, covers about 19 million $\mathrm{km}^{2}$ from western Africa to western India. These are generally low-lying areas $(<1000 \mathrm{~m})$ with a tropical desert or semi-desert climate. The average annual temperature is around $20-30^{\circ} \mathrm{C}$, the average monthly temperature from July to October is above $30^{\circ} \mathrm{C}$, and the annual rainfall is very low and below $250 \mathrm{~mm}$ [2]. Rainfall over $25 \mathrm{~mm}$ in two consecutive months is usually assumed to be enough for locust breeding and development [27]. In the highlands of Tibet, in areas where locusts have been observed, climatic conditions are quite different and a priori not very conducive to the survival of new arrivals. The average annual temperature is about $8{ }^{\circ} \mathrm{C}$ in southern Tibet. Zhangmu area, at relatively low elevations of $1700-3800 \mathrm{~m}$, has a humid or semi-humid subtropical monsoonal plateau climate. Rainfall is abundant with an annual average of $2820 \mathrm{~mm}$ and a rainy season extending from June to October. The average daily temperature during this season is less than $20^{\circ} \mathrm{C}$ or even $10^{\circ} \mathrm{C}$ in the highest areas such as Qu City [33,34]. Areas 
at elevations above $3800 \mathrm{~m}$, such as Nyalam, have a plateau mountain climate where the highest daily temperature in August is mostly below $20^{\circ} \mathrm{C}$ and the nighttime temperature is close to $0^{\circ} \mathrm{C}$ [35-37].

The lowest temperature at which locusts can migrate and propagate over a long distance is $20^{\circ} \mathrm{C}[27,38-40]$ and this limiting temperature is even higher (about $23^{\circ} \mathrm{C}$ ) if the sky is overcast, with insufficient sunlight rendering locusts unable to absorb sufficient heat energy [26,27]. Therefore, temperatures in Tibet make it nearly impossible for locusts to fly uninterrupted over long distances. Furthermore, above $4000 \mathrm{~m}$, the oxygen content of the air is only about $14.6 \%$, well below the $21.0 \%$ recorded in Africa at sea level [41-43]. Decreased oxygen availability (and decreased temperature) make life at such altitudes challenging. The physiological effects of environmental hypoxia may indeed contribute to limiting the ability of insects to persist at high altitudes [44]. This lack of oxygen at high altitudes must therefore have been another limiting factor in locust flight activity in Tibet. This reduced flight ability is probably responsible for the large number of drowned locusts found in small ponds and lakes in the Qu town area (3365 $\mathrm{m})$ and at Langqiang Lake $(4670 \mathrm{~m})$, where individuals have been observed falling into the water, even on a sunny day, and although adults are accustomed to avoiding water when flying.

These extreme climatic conditions for desert locusts in the Tibetan highlands appear to have affected not only the flight ability of individuals but also their survival and reproductive ability. In a field cage, with sufficient food and no natural enemies, the average life span of desert locust adults was 26 days in Zhangmu (at $2300 \mathrm{~m}$ elevation) and 71 days in Nyalam (at $3800 \mathrm{~m}$ ). Such life spans seem short even considering that these are immigrant individuals with only part of their imaginal life observed, with the average duration normally ranging from 2.5 to 5 months [27]. This longevity appears to have been significantly shortened even though many individuals remained immature, a state in which locusts can normally remain quiescent for several months until suitable conditions return.

Other evidence suggests that the locusts that entered Tibet were placed in unfavorable conditions.

First of all, they had a low food intake since $72 \%$ of the locusts collected in the field had an empty digestive tract. In the cages, the locusts also showed a reduced feeding activity. The majority of local plants tested appeared to have low palatability. Even though they represent a small proportion of the flora of Tibet, one third of these plants were not consumed or were consumed only slightly, which is surprising considering the very polyphagous nature of the desert locust. It is interesting to note that of the 34 plants tested, 15 belong to genera that are not represented in the usual range of this insect.

Secondly, sexual maturation was disturbed. In Zhangmu area, 99.4\% of the females were immature. In the field cage only $10.0 \%$ of the females were observed in early maturation. In the Langqiang Lake area, $55.6 \%$ of the females were immature, the rest were in various stages of ovarian development, but none had laid eggs. In Nyalam, in a cage, only one female laid eggs while the other 35 tested died before laying eggs. In the end, most of the locusts died quickly in the immature state. For sexually matured females, the time from adult emergence to first matings was 43 days at $3800 \mathrm{~m}$, whereas it may be as little as 15 days under optimal thermal conditions [27,45,46].

Finally, no eggs were observed except for one, containing 78 eggs, none of which hatched after incubation in the laboratory. At best, the embryonic development time was strongly slowed down by the low temperatures. Desert locust eggs require an air temperature of $20-35^{\circ} \mathrm{C}$ and a soil temperature of $15.5-35^{\circ} \mathrm{C}$, low temperatures make egg survival impossible $[27,47,48]$. On the Tibetan plateau, the winter temperature is very low and the snow is deep. Even if locusts were successful in laying eggs, they would probably not withstand the low temperatures.

In conclusion, the combined influences of low temperatures, high precipitation, high altitude and low oxygen content, and unfavorable food supply weakened the immigrant locust populations, reduced their flight ability, disrupted sexual maturation, and made egg laying almost impossible. In addition, various natural enemies must have contributed 
to rapidly limiting the populations, including various birds and entomopathogenic fungi actually observed. In the end, these locusts died quickly without any local offspring and without having been able to cross the Himalayan barrier.

Author Contributions: L.Z. and J.L. conceived the study, performed the field work, and collected data; J.L., M.L. and L.Z. wrote the first draft of the manuscript; all authors contributed substantially to data analysis, writing, review and editing. All authors have read and agreed to the published version of the manuscript.

Funding: This work was supported by grants from The Ministry of Agriculture and Rural Affairs of China (15206030 and 12210030), and the grant for innovation project from Shandong Academy of Agricultural Sciences (CXGC2021B12).

Conflicts of Interest: Authors declare no competing interests.

\section{Appendix A}

Desert locust invasion pathways, survival, and reproduction on the Tibetan Plateau in China. The desert locust swarms cannot pass the high-altitude but enter through the lower parts of the Himalayan river valleys. A limited number of locusts climb along the river valleys, step by step. When the altitude exceeds $3000 \mathrm{~m}$, only a few locusts can fly and some may fall suddenly in flight. They are not adapted to the low temperatures and high humidity of the plateau climate and eventually die abnormally and are unable to reproduce.

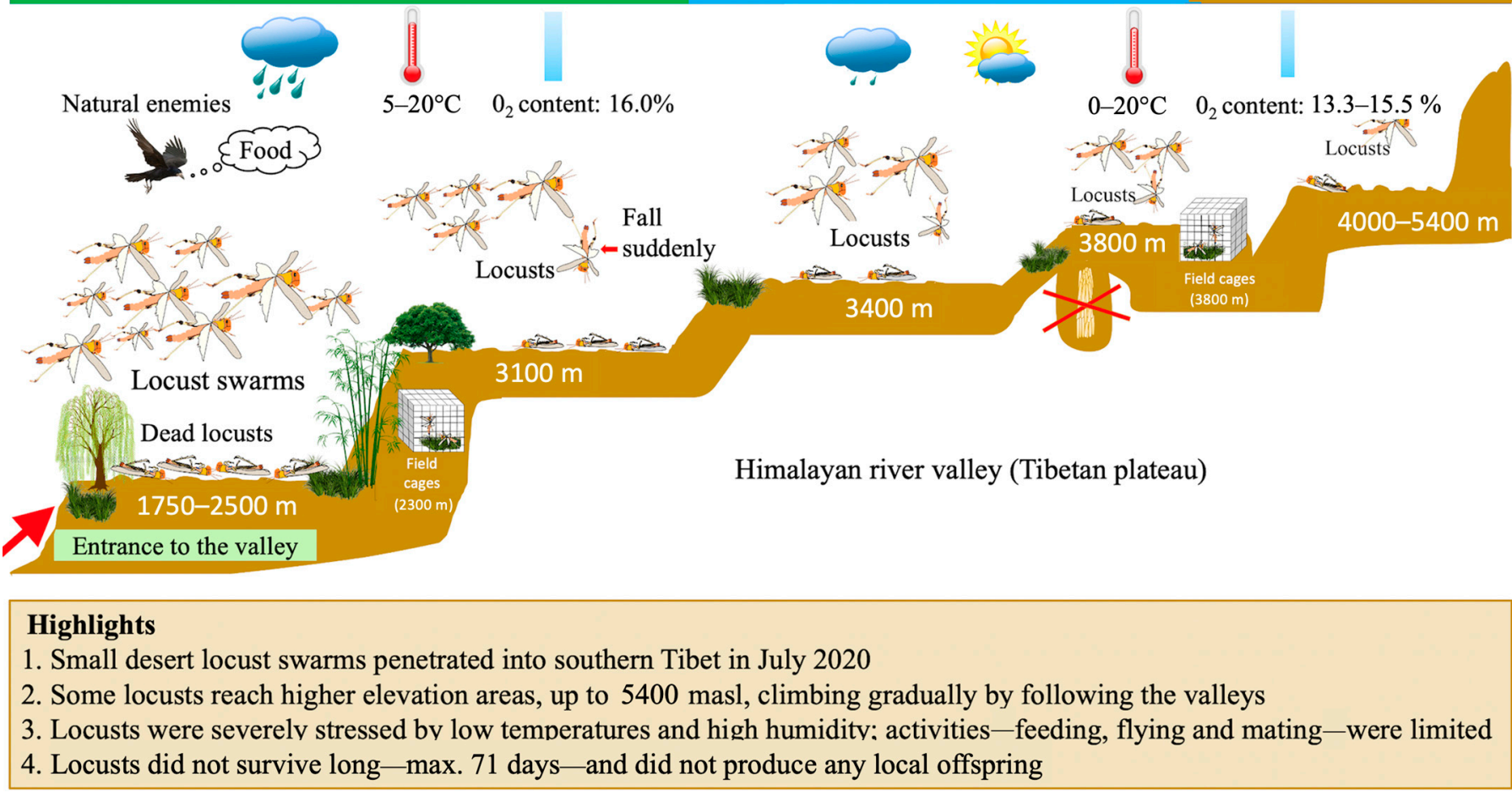

Figure A1. Desert locust invasion pathways, survival, and reproduction on the Tibetan Plateau in China.

\section{References}

1. Bennett, L.V. The development and termination of the 1968 plague of the desert locust, Schistocerca gregaria (Forskål) (Orthoptera, Acrididae). Bull. Entomol. Res. 1976, 66, 511-552. [CrossRef]

2. Steedman, A. Locust Handbook, 3rd ed.; Overseas Development Natural Resource Institute: London, UK, 1990.

3. Despland, E. Diet breadth and anti-predator strategies in desert locusts and other Orthopterans. J. Orthoptera Res. 2005, 14, 227-233. [CrossRef]

4. Roffey, J.; Popov, G. Environmental and behavioural processes in a desert locust outbreak. Nature 1968, 219, 446-450. [CrossRef] 
5. Magor, J.I.; Lecoq, M.; Hunter, D.M. Preventive control and Desert Locust plagues. Crop Prot. 2008, 27, 1527-1533. [CrossRef]

6. Kennedy, J.S. The migration of the desert locust (Schistocerca gregaria Forsk). I. The Behaviour of Swarms. II. A theory of long-range migrations. Philos. Trans. R. Soc. Lond. B Biol. Sci. 1951, 235, 163-290.

7. Lorenz, M.W. Migration and trans-Atlantic flight of locusts. ScienceDirect 2009, 196, 4-12. [CrossRef]

8. Uvarov, B.P. A revision of the genus Locusta, L. (= Pachytylus, Fieb.), with a new theory as to the periodicity and migrations of locusts. Bull. Entomol. Res. 1921, 12, 135-163. [CrossRef]

9. Uvarov, B.P. Locust as a world problem. In Proceedings of the Première Conférence Internationale Pour la Protection Contre les Calamités Naturelles, Paris, France, 13-17 September 1937; Commission Française d'études des Calamités with the Support of Union Internationale de Secours: Paris, France, 1938; pp. 376-382.

10. Uvarov, B.P. Grasshoppers and Locusts: A Handbook of General Acridology. II: Behaviour, Ecology, Biogeography, Population Dynamics; Centre for Overseas Pest Research: London, UK, 1977.

11. Magor, J.I.; Ceccato, P.N.; Dobson, H.M.; Pender, J.; Ritchie, L. Preparedness to Prevent Desert Locust Plagues in the Central Region, an History Review, No. AGP/DL/TS/35; Food and Agriculture Organization of the United Nations: Rome, Italy, 2007. Available online: http:/ / www.fao.org/ag/locusts/common/ecg/1288/en/TS35ePart1text.pdf (accessed on 17 June 2021).

12. Symmons, P.M.; Cressman, K. Desert Locust Guidelines 1. Biology and Behavior; Food and Agriculture Organization of the United Nations: Rome, Italy, 2001. Available online: http:/ / www.fao.org/ag/LOCUSTS/common/ecg/347_en_DLG1e.pdf (accessed on 17 June 2021).

13. Cressman, K. Desert Locust. In Biological and Environmental Hazards, Risks, and Disasters; Shroder, J.F., Sivanpillai, R., Eds.; Elsevier: Amsterdam, The Netherlands, 2016; pp. 87-105.

14. Zhang, L.; Lecoq, M.; Latchininsky, A.; Hunter, D. Locust and Grasshopper Management. Annu. Rev. Entomol. 2019, 64, 15-34. [CrossRef]

15. FAO. Desert Locust Bulletin. No. 486, General Situation during March 2019; Food and Agriculture Organization of the United Nations: Rome, Italy, 2019. Available online: http:/ / www.fao.org/ag/locusts/common/ecg/2471/en/DL486e.pdf (accessed on 17 June 2021).

16. FAO. Desert Locust Bulletin. No. 488, General Situation during May 2019; Food and Agriculture Organization of the United Nations: Rome, Italy, 2019. Available online: http:/ / www.fao.org/ag/locusts/common/ecg/2475/en/DL488e.pdf (accessed on 17 June 2021).

17. FAO. Desert Locust Bulletin. No. 501, General Situation during June 2020; Food and Agriculture Organization of the United Nations: Rome, Italy, 2020. Available online: http:/ / www.fao.org/ag/locusts/common/ecg/2556/en/DL501e.pdf (accessed on 17 June 2021).

18. FAO. Desert Locust Bulletin. No. 502, General Situation during July 2020; Food and Agriculture Organization of the United Nations: Rome, Italy, 2020. Available online: http:/ / www.fao.org/ag/locusts/common/ecg/2559/en/DL502e.pdf (accessed on 17 June 2021).

19. Waloff, Z. The upsurges and recessions of the Desert Locust plague: An historical survey. Anti-Locust Mem. 1966, 8, 1-111.

20. Waloff, Z. Some temporal characteristics of Desert Locust plagues. Anti-Locust Mem. 1976, 13, 1-36.

21. COPR. The Locust and Grasshopper Agricultural Manual; Centre for Overseas Pest Research: London, UK, 1982.

22. Chen, Y.L. A new record of the desert locust, Schistocerca gregaria (Forskål) in Tibet, China. Acta Entomol. Sin. $1982,25,67$.

23. Chen, Y.L. Watch out for the outbreaks of desert locusts. Entomol. Knowl. 2002, 39, 335-339.

24. Cai, B.H. Taxonomy of Insects; Financial and Economic Publishing House: Beijing, China, 1956; Volume 1.

25. Zhang, W. Will Desert Locust Invade Tibet? It's not just the Himalayas that Stand in Front of It. Available online: https: / / www.tellerreport.com/life/2020-03-13---will-desert-locust-invade-tibet---it- \T1 \textquoterights-not-just-thehimalayas-that-stand-in-front-of-it-.BJDLn1YH8.html (accessed on 1 September 2021).

26. Rainey, R.C. Biometeorology and insect flight: Some aspects of energy exchange. Annu. Rev. Entomol. 1974, 19, 407-439. [CrossRef]

27. Cressman, K.; Stefanski, R. Weather and Desert Locusts; WMO-No. 1175; WMO: Geneva, Switzerland; FAO: Rome, Italy, 2016. Available online: https:/ /library.wmo.int/doc_num.php?explnum_id=3213 (accessed on 17 June 2021).

28. Schaefer, G.W. Radar detection of individual locusts and swarms. In Proceedings of the International Study Conference on the Current and Future Problems of Acridology, London, UK, 6-16 July 1970; Hemming, C.F., Taylor, T.H.C., Eds.; Centre for Overseas Pest Research: London, UK, 1972; pp. 379-380.

29. Alexander, G. Occurrence of grasshoppers as accidentals in the Rocky Mountains of northern Colorado. Ecology 1964, 45, 77-86. [CrossRef]

30. Rainey, R.C. Meteorology and the migration of desert locusts. In Applications of a Synoptic Meteorology in Locust Control; Technical Notes, No. 54; World Meteorological Organization: Geneva, Switzerland, 1963. [CrossRef]

31. Shrestha, S.; Thakur, G.; Gautam, J.; Acharya, N.; Shrestha, J. Desert locust and its management in Nepal: A review. J. Agric. Nat. Resour. 2021, 4, 1-28.

32. Karki, S. Locust: Winged-Terror Declines Gradually in Nepal; Khabarhub: Kathmandu, Nepal, 2020. Available online: https: / /english.khabarhub.com/2020/07/110094/ (accessed on 1 September 2021).

33. Jia, S.L.; Wang, Q.; Li, L.; Fang, X.K.; Shi, Y.H.; Xu, W.G.; Hu, J.H. Comparative study on PCDD/F pollution in soil from the Antarctic, Arctic and Tibetan Plateau. Sci. Total Environ. 2014, 497, 353-359. [CrossRef] 
34. Liu, D.X.; Tong, B.; Yang, Y.S.; Yao, X.Y.; Ding, Y.; Xia, Z.Y. Basic Characteristics and Proneness Evaluation about Debris Flow in Zhangmu Gully of Tibet. Electron. J. Geotech. Eng. 2016, 21, 7433-7446.

35. Liu, X.D.; Chen, B.D. Climatic warming in the Tibetan Plateau during recent decades. Int. J. Climatol. 2000, $20,1729-1742$. [CrossRef]

36. Wu, G.X.; Duan, A.; Liu, Y.; Mao, J.; Ren, R.; Bao, Q.; He, B.; Liu, B.; Hu, W. Tibetan Plateau climate dynamics: Recent research progress and outlook. Natl. Sci. Rev. 2015, 2, 100-116. [CrossRef]

37. Wu, S.H.; Yin, Y.H.; Zheng, D.; Yang, Q.Y. Climate changes in the Tibetan Plateau during the last three decades. Acta Geogr. Sin. 2005, 60, 3-11.

38. Neville, A.C.; Weis-Fogh, T. The effect of temperature on locust flight muscle. J. Exp. Biol. 1963, 40, 111-121. [CrossRef]

39. Roffey, J. Observations on gliding in the desert locust. Anim. Behav. 1963, 11, 359-366. [CrossRef]

40. Weis-Fogh, T. Biology and physics of locust flight II. Flight performance of the desert locust (Schistocerca gregaria). Philos. Trans. R. Soc. Lond. B Biol. Sci. 1956, 239, 459-510.

41. Harrison, J.F.; Kaiser, A.; VandenBrooks, J.M. Atmospheric oxygen level and the evolution of insect body size. Philos. Trans. $R$. Soc. Lond. B Biol. Sci. 2010, 277, 1937-1946. [CrossRef]

42. Hoback, W.W.; Stanley, D.W. Insects in hypoxia. J. Insect Physiol. 2001, 47, 533-542. [CrossRef]

43. Rascón, B.; Harrison, J.F. Oxygen partial pressure effects on metabolic rate and behavior of tethered flying locusts. J. Insect Physiol. 2005, 51, 1193-1199. [CrossRef]

44. Dahlhoff, E.P.; Dahlhoff, V.C.; Grainger, C.A.; Zavala, N.A.; Otepola-Bello, D.; Sargent, B.A.; Roberts, K.T.; Heidl, S.J.; Smiley, J.T.; Rank, N.E. Getting chased up the mountain: High elevation may limit performance and fitness characters in a montane insect. Funct. Ecol. 2019, 33, 809-818. [CrossRef]

45. Duranton, J.F.; Lecoq, M. Le Criquet pèlerin au Sahel; Collection Acridologie Opérationnelle n6; Comité Inter-Etats de Lutte contre la Sécheresse dans le Sahel, Département de Formation en Protection des Végétaux: Niamey, Niger, 1990. Available online: http:/ / locust.cirad.fr/ouvrages_pratiques/pdf/DFPV6.pdf (accessed on 2 June 2021).

46. Norris, M.J. Reproduction in the desert locust Schistocerca gregaria (Forsk.) in relation to density and phase. Anti-Locust Bull. 1952, $13,1-49$.

47. Gómez, D.; Salvador, P.; Sanz, J.; Casanova, C.; Taratiel, D.; Casanova, J.L. Desert locust detection using Earth observation satellite data in Mauritania. J. Arid Environ. 2019, 164, 29-37. [CrossRef]

48. Huque, H.; Jaleel, M.A. Temperature-Induced Quiescence in the Eggs of the Desert Locust. J. Econ. Entomol. 1970, 63, 1398-1400. [CrossRef] 